\title{
The Use Of Debates Of Current Economic Issues As An Aid For Developing Critical Thinking Skills
}

Patricia T. Papachristou, (E-mail: ppapachr@cbu.edu), Christian Brothers University

\begin{abstract}
Economics is exciting because it can deal effectively with critical public policy issues. Unfortunately, this aspect of economics is usually left for more advanced courses. Consequently many students find principles of economics boring and not relevant to the real world. The use of public policy issues can foster greater student involvement in the learning process with a higher level of critical thinking skills.
\end{abstract}

\section{INTRODUCTION}

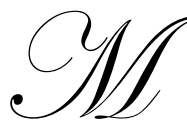

y use of debates of current economic issues has evolved from something students did for extra-credit in class by a panel of four students to the full involvement of all members of the class in reading and discussing the issues prior to the formal debate. Instead of just the panel of debate students getting ten extra-credit points on a test, now the class will have an option of doing a twenty point take-home essay that will be turned in the last day of class and take the place of an essay on the final exam. About ten years ago I started with the book Taking Sides: Clashing Views on Controversial Economic Issues which has seventeen issues with an introductory issue summary done by Thomas R. Swartz and Frank J. Bonello, two economic professors at the University of Notre Dame. The book had two reprinted articles that represented opposing views on such questions as Should Social Security be privatized, Is it time to abolish the minimum wage, Has the North American Free Trade Agreement hurt the American economy, Should pollution be put to the market test and Should Cities Subsidize Sports and Sports Venues. These articles are from an assortment of periodicals and a variety of disciplines.

Now I am using Economic Issues Today: Alternative Approaches by economists Robert Carson, Wade L. Thomas and Jason Hecht. The book discusses fourteen issues from three political perspectives. The micro issues discussed are "Competition or Protection for American Agriculture," "Is it necessary to protect the consumer," How can we save the environment," "Is big business a threat or a boon," Does America have an income inequality problem," and "What is a fair system of taxation". The problems of aggregate economic policy include "Macroeconomic instability: Are we depression proof?, Balancing the Federal Budget: Should we be worried about the rising federal deficit?, Economic Growth and Stability: Can we maintain high and steady rates of economic growth?, Inflation: Can price pressures be kept under control?, The New Population Problem: Can we save our Social Security System? And Where Does America Fit into the New World Order?". From the book Economic Issues Today (2005), students will learn the three alternatives perspectives of Conservatives, Liberals, and Radicals "in theory" and then see how they are applied to specific micro and macroeconomic issues. On the first day of class students can decide which three out of seven issues will be formally debated.

The initial objective is to have students be able to follow an intellectual argument from each of the three perspectives. The final objective is to have students demonstrate their understanding of these political perspectives by writing a comparative essay (approximately 1000 words) on the three issues which have been debated in class. This can be done as a take home essay as part of the final exam. The ultimate goal is value clarification so students will understand the three perspectives and be able to see side that each side can bring up arguments of merit that may lead them to "refine their view." 


\section{THE MECHANICS OF DEBATE PREPARATION}

Approximately once a month there will be a debate. The debate will consist of four parts: opening statement, main arguments, rebuttal, and closing statement. All students will read the twenty page chapter which covers the three perspectives. The class will be divided into six groups so that each perspective will be discussed by two groups. This gives students the chance to interact with their peers and exert informal pressure on them to be prepared for the small discussion group. During the semester they will be concerned and participate in discussions from all three perspectives. The people making up the discussion group can be changed by mixing up the two groups for each perspective. Totally changing all groups for each perspective will make it harder to administer and see that everyone does each perspective. A discussion leader will summarize the team's understanding of the main assumptions and arguments for their perspective. All students will write a five hundred word brief outlining the three perspectives, but emphasizing their assigned perspective for each of the debate topics. This will be turned in the class before the formal debate.

Six students will be selected to participate in the formal debate and can earn extra-credit points. In preparation for the debate each side will outline the main parts of the debate and distribute the handout to the class. For the rebuttal, students will have to anticipate the main arguments of the other side and be prepared with good counterpoints. After the closing statements, the audience will be given the opportunity to ask questions.

\section{VALUE OF DEBATES}

The debates demonstrate the distinction between normative and positive economics. The debate format allows students to observe how normative values affect empirical studies that are done. The debates clearly show that these issues are not 'settled' and that it is important to be able to develop a logical and empirically supported argument for your side while acknowledging that the other side may also have some merit to their argument.

This is good for economics because students will find the course much more interesting and "alive" because it is concerned with current public policy issues. Many students enjoy the give and take of the debate format. Even if they are not on the debate panel, they can participate mentally and orally because they have already taken part in small group discussions in a previous class period and have had to write a summary essay comparing the three political perspectives on the issue.

\section{CONCLUSION}

Becoming educated involves developing the skills of rational discourse and modifying your views when appropriate. The ideological polarization in the United States increases the desirability of showing how rational people can disagree while acknowledging that the other side has some legitimate concerns that need to be addressed. The debate topics are complex issues that often involve competing values of equity, efficiency and stability. Students can see that higher level thinking skills are required for these assignments and have enriched the class by their active participation in small group discussion and as an engaged audience seeing lively, informed debates. This brings a level of excitement to our class that is unfortunately not often associated with principles of economics.

\section{REFERENCES}

1. Becker, William E. and Michael Watts. Teaching Economics to Undergraduates: Alternatives to Chalk and Talk. Northampton, MA: Edward Elgar,1998.

2. Carson, Robert B., Wade L. Thomas, et al. Economic Issues Today: Alternative Approaches. Armonk, NY: M.E. Sharpe, 2005.

3. Swartz, Thomas R. and Frank J. Bonello, Taking Sides: Clashing Views on Controversial Economic Issues. Guilford, CT: McGraw-Hill, 2004. 